... Krilek, Ťavodová, Kováč, Tichý: Impact of Irregular Tooth Pitch of Circular Saw Blades...

Jozef Krilek, Miroslava Ťavodová, Ján Kováč, Branislav Tichýl

\title{
Impact of Irregular Tooth Pitch of Circular Saw Blades on Power for Wood Cross-Cutting
}

\section{Utjecaj promjenjivog koraka zubi kružnih pila na snagu za poprečno rezanje drva}

\author{
Original scientific paper • Izvorni znanstveni rad \\ Received-prispjelo: 15. 6. 2018. \\ Accepted-prihvaćeno: 20. 11. 2019 \\ UDK: $630 * 822.331$ \\ https://doi.org/10.5552/drvind.2020.1824
}

\author{
(C) 2020 by the author(s) \\ Licensee Faculty of Forestry, University of Zagreb. \\ This article is an open access article distributed \\ under the terms and conditions of the \\ Creative Commons Attribution (CC BY 4.0) license.
}

\begin{abstract}
The article deals with the influence of irregular tooth pitch on energy consumption of cross-cutting wood. In this article, the effect was assessed of feeding velocity and parameters of saw blade on the cutting power Pc of spruce (Picea Abies), pine (Pinus Sylvestris) and beech (Fagus Silvatica) wood during sawing with a guided circular saw. For the research, two types of circular saw blades were used, one of them having irregular tooth pitch. The circular saw blades had sintered carbide inserts with a diameter of $D=350 \mathrm{~mm}$ and the same number of teeth. The feed velocities were $v_{f}=4,8,12 \mathrm{~m} \cdot \mathrm{min}^{-1}$ and revolutions $n=3000 \mathrm{~min}^{-1}$. The results showed that the circular saw blades with irregular tooth pitch have higher energy consumption than the circular saw blades with regular tooth pitch. The highest cutting power Pc was shown in the case of beech. It was also shown that energy consumption is increasing linearly with increasing feed velocity.
\end{abstract}

Key words: energy consumption; cross-cutting wood; circular saw blades; cutting power; irregular tooth pitch

SAŽETAK • U radu se prikazuje istraživanje utjecaja promjenjivog koraka zubi kružnih pila na potrošnju energije pri poprečnom rezanju drva. Analiziran je utjecaj posmične brzine, parametara lista pile $i$ vrste drva na snagu rezanja $(P)$. Eksperiment je proveden piljenjem drva smreke (Picea abies), bora (Pinus sylvestris) i bukve ( $\underline{\text { Fagus }}$ silvatica) vođenom kružnom pilom. Za istraživanje su rabljena dva lista kružnih pila, od kojih je jedan imao promjenjivi korak zubi. Oba su lista kružnih pila imala oštrice od sinteriranih karbidnih umetaka, promjer lista $D=$ $350 \mathrm{~mm}$ i jednak broj zubi. Primijenjene su tri posmične brzine: 4, 8 i $12 \mathrm{~m} \cdot \mathrm{min}^{-1}$, a broj okretaja radnog vratila iznosio je $n=3000 \mathrm{~min}^{-1}$. Rezultati su pokazali da je potrošnja energije kružnih pila s promjenjivim korakom zubi veća od potrošnje energije kružnih pila s jednakim korakom zubi. Najveća snaga rezanja $P_{c}$ zabilježena je pri piljenju bukve. Uočeno je da se potrošnja energije linearno povećava s povećanjem posmične brzine.

Ključne rïječi: energetska potrošnja; poprečno piljenje drva; listovi kružne pile; snaga rezanja; promjenjivi korak zubi

\section{INTRODUCTION \\ 1. UVOD}

In practice, in the wood cutting process, it is important to keep energy consumption at the lowest pos- sible level. Impacts affecting energy consumption are e.g. cutting conditions (feed per tooth $f_{z}$, cutting speed $v_{\mathrm{c}}$, feed velocity $v_{\mathrm{f}}$ ), the choice of material suitable for a cutting tool and geometry of a tool. The cutting pow-

\footnotetext{
${ }^{1}$ The authors are associate professor, associate professor, associate professor and PhD student at the Faculty of Technology, Technical University in Zvolen, Zvolen, Slovak Republic.
} 


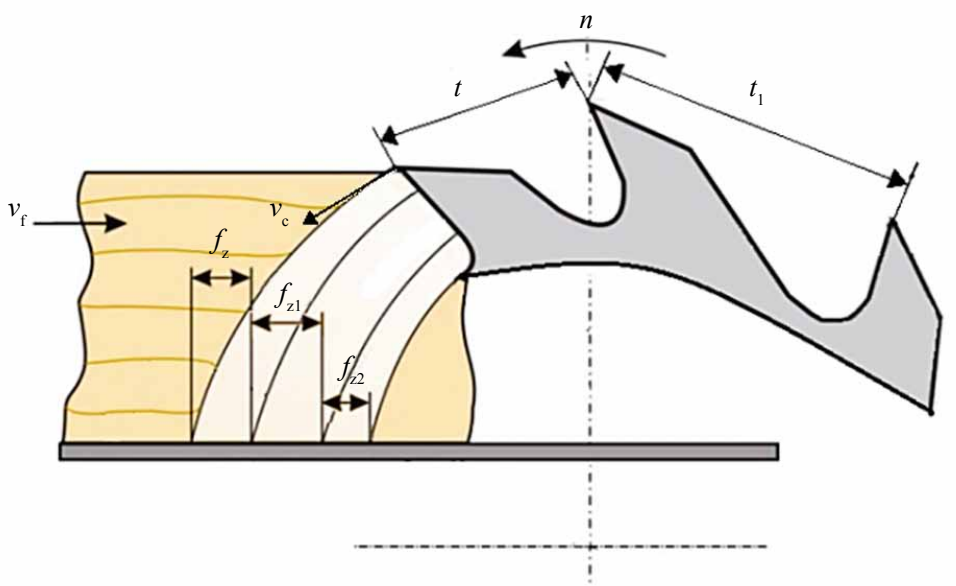

Figure 1 Kinematic scheme of a circular saw blade: $f_{z}$ - feed per tooth for regular tooth pitch circular saw blades; $f_{\mathrm{zl}, 2}-$ feed per tooth for irregular tooth pitch of circular saw blades; $t$ - tooth spacing for regular tooth pitch circular saw blades; $t_{1}$ - tooth spacing for irregular tooth pitch of circular saw blades; $h_{\mathrm{z}}$ - height of a tooth; $v_{\mathrm{c}}$ - cutting speed; $v_{\mathrm{f}}$ - feed velocity; $\alpha$ - clearance angle; $\beta$ - cutting edge angle; $\gamma$ - rake angel; (Siklienka et al., 2013)

Slika 1. Kinematička shema lista kružne pile: $f_{z}$ - posmak po zubu za list kružne pile s jednakim korakom zubi; $f_{z 1,2}-$ posmak po zubu za list kružne pile s promjenjivim korakom zubi; $t$ - duljina koraka zubi lista kružne pile s jednakim korakom zubi; $t_{1}$ - duljina koraka zubi lista kružne pile s promjenjivim korakom zubi; $h_{\mathrm{z}}$ - visina zubi; $v_{\mathrm{c}}$ - brzina rezanja; $v_{\mathrm{f}}-$ posmična brzina; $\alpha$ - leđni kut; $\beta$ - kut oštrice; $\gamma$ - prsni kut (Siklienka et al., 2013.)

er is one of the most important factors affecting energy consumption (Atkins, 2009; Barcík et al. 2009; Danwé et al., 2012).

For the quality of a processed surface, efficiency of machines and tools, and dimensions of a product, it is necessary to provide proper cutting conditions and cutting angles (Argay, 2014; Banski, 2000; Manžos, 1974). Inappropriate cutting angles can result in bad quality of a processed surface, higher possibility of tool wear, lower lifetime of a tool and finally questionable reliability of the whole machine (Goglia, 1994; Mikleš et al., 2010; Kminiak et al. 2015; Kvietková et al., 2015; Lisičan, 1982).

\subsection{Cross-cutting wood by circular saws \\ 1.1. Poprečno rezanje drva kružnom pilom}

Cutting wood by circular saw blades is a complex process. For getting ideal operating conditions, it is important to know mutual interaction among a tool, a product and influence of technical and technological factors affecting the cutting power and final quality of the product. It is possible to obtain the required quality by setting these factors and parameters. Cutting quality is affected by tool wear.
Circular saw blade cutting is the most widely spread way of wood sawing. Owing to different design and construction of circular saw blades, it is possible to cut in different ways with respect to the wood fibers (Kminiak et al., 2016; Strelkov, 2009; Naylor et al., 2012).

Using three basic criteria, we can evaluate the impacts on wood cutting and processing, i.e. a machine, a tool and a processed object. The criteria are defined in Tab. 1 (Mikleš et al., 2010).

The kinetic equations for cross-cutting are analogous to rip cutting. A cutting speed of $40-75 \mathrm{~m} \cdot \mathrm{sec}^{-1}$ is recommended; if the saw blade temperature drops along its radius, it does not reach its maximum at this speed, in the case of $0{ }^{\circ} \mathrm{C}$ (cross-cutting itself in the working cycle is less than $10 \%$ ); this means that an increase in temperature in the saw blade is not considered. The selection of a cutting speed also considers the working limits of the saw blade shaft bearings, as well as the noise level, the wear of the cutting edges $\left(v_{\mathrm{c}}<60 \mathrm{~m} \cdot \mathrm{sec}^{-1}\right)$ and energy consumed by cutting $\left(v_{\mathrm{c}}=60-80 \mathrm{~m} \cdot \mathrm{sec}^{-1}\right)$.

Cutting power is an important parameter and it is interesting for every wood processor using machines with respect to energy consumption of the machine

Table 1 Criteria affecting cutting process (Mikleš et al. 2010)

Tablica 1. Kriteriji koji utječu na proces rezanja (Mikleš i sur., 2010.)

\begin{tabular}{|c|c|c|c|}
\hline $\begin{array}{l}\text { Criteria } \\
\text { Kriteriji }\end{array}$ & Product / Proizvod & Machine / Stroj & Tool / Alat \\
\hline $\begin{array}{l}\text { External } \\
\text { vanjski }\end{array}$ & $\begin{array}{l}\text { chip shape, cutting depth, cutting quality } \\
\text { oblik strugotine, visina rezanja, kvaliteta } \\
\text { rezanja }\end{array}$ & $\begin{array}{l}\text { feed velocity, cutting forces, material, cutting } \\
\text { speed, vibrations, lifetime, cutting power } \\
\text { posmična brzina, sile rezanja, materijal, brzina } \\
\text { rezanja, vibracije, vijek trajanja, snaga rezanja }\end{array}$ & $\begin{array}{l}\text { wear, geometry of } \\
\text { the cutting edge } \\
\text { trošenje, geometrija } \\
\text { rezne oštrice }\end{array}$ \\
\hline $\begin{array}{l}\text { Internal } \\
\text { unutarnji }\end{array}$ & $\begin{array}{l}\text { wood species, wood strength, direction of } \\
\text { fiber cutting, wood moisture, wood density } \\
\text { vrsta drva, čvrstoća drva, smjer rezanja s } \\
\text { obzirom na smjer vlakanaca, sadržaj } \\
\text { vode, gustoća drva }\end{array}$ & $\begin{array}{l}\text { material properties, type of material } \\
\text { svojstva materijala, vrsta materijala }\end{array}$ & $\begin{array}{l}\text { material properties, } \\
\text { type of material } \\
\text { svojstva materijala, } \\
\text { vrsta materijala }\end{array}$ \\
\hline
\end{tabular}


used (Mikleš et al., 2010; Scholz et al., 2009). The goal of wood processors should be to achieve the required quality and product parameters at the lowest possible production costs (Kopecký et al., 2007; Siklienka et al., 2012; Siklienka et al., 2005). It is possible to decrease wood cutting costs and increase cutting power and cutting accuracy by a suitable tool, its geometry and cutting conditions (Wasielewski et al., 1999; Barcík et al., 2008).

Decreasing energy consumption of a machine has a significant impact on the whole value of the final product (Bradbury et al., 2000; Schajer et al., 2002). Power requirements and performance of the machine are defined according to STN ISO 3002-4. Wood is anisotropic material and its properties vary in different parts of the trunk, and that is the reason why it is difficult to define K (Vladimirovič, 2004; Suchanov, 2015).

Nowadays, the specific cutting resistance $\mathrm{k}_{\mathrm{c}}$ is defined according to empirical formulas obtained by long time wood research and experiments. Many parameters are used such as wood species $K_{\mathrm{d}}$, cutting model $K_{\varphi}$, cutting angle $K_{\delta}$, cutting speed $K_{\mathrm{v}}$, wood moisture $K_{\mathrm{w}}$, tool wear $K_{\rho}$ and thickness of chips $h$ (Kopecký et al., 2014; Kováč et al., 2009; Orlowski et al., 2006; Svoreň, 2002).

\section{MATERIALS AND METHODS}

\section{MATERIJALI I METODE}

\subsection{Tested samples}

2.1. Ispitni uzorci

The measurement was carried out by using spruce (Picea Abies), pine (Pinus Sylvestris) and beech (Fagus Silvatica). The dimensions of tested samples were $50 \mathrm{~mm} \times 200 \mathrm{~mm} \times 1000 \mathrm{~mm}$. These dimensions were chosen on the basis of technical parameters of the measuring equipment.

The moisture of tested samples was defined by gravimetric analysis in accordance with SS-EN13183-1. This method belongs to direct methods defining wood moisture. The principle of this method is based on the definition of the wet wood weight followed by drying and repeated weighing (Požgaj et al., 1997; Orlowski, 2007). The mean value of moisture of wooden samples was $27 \%$.

\subsection{Circular saw blades}

\subsection{Listovi kružnih pila}

For experimental tests, two circular saw blades were used i.e. circular saw blades with sintered carbide inserts.

The circular saw blades have the same number of teeth and tooth geometry. The first circular saw blade has regular tooth pitch and a full body (Fig. 2). The second circular saw blade has irregular tooth pitch and its body has dilatation gaps for decreasing stress and vibrations in the process of cutting wood (Fig. 3). It is also possible to see in details different shape of teeth (Fig. 3 and 4). Parameters of the circular saw blades are shown in Tab. 2.

The wood cross-cutting process was performed in the testing device shown in Figure 5. This equipment is used for testing wood cutting conditions. It was designed at the Technical University in Zvolen (Slovakia), the Faculty of Environmental and Manufacturing Technology, Department of Environmental and Forest Machinery. The equipment consists of two main parts i.e. feed and cutting parts (Fig. 5).

The transfer of torque on the tested circular saw blade is ensured by the cutting mechanism. Keeping and feeding of the processed material to the place of cutting is ensured by the feed mechanism.

The working desk (Fig. 5) consists of a threephase asynchronous electric motor of $7.5 \mathrm{~kW}$. The torque is transferred by the belt from the safety clutch GIFLEX GFLL - 28, through the input clutch of a torque sensor, torque sensor HBM T20WN (Fig. 5),
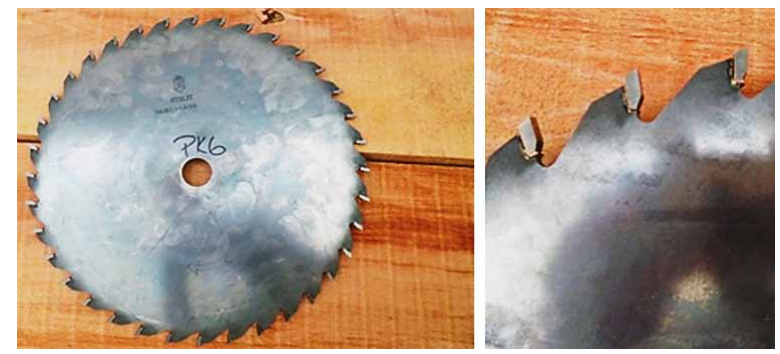

Figure 2 Circular saw blade 1 with regular tooth pitch and full body

Slika 2. List kružne pile $1 \mathrm{~s}$ jednakim korakom zubi i punim tijelom
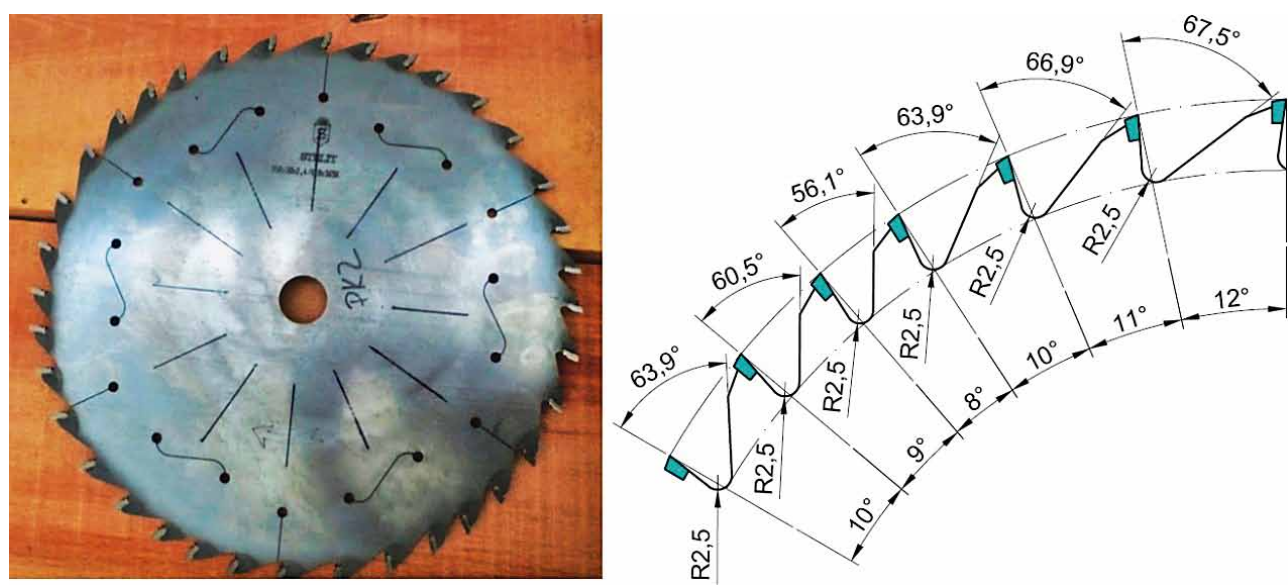

Figure 3 Circular saw blade 2 with irregular tooth pitch and body with dilatation gaps (Svoreň et al., 2013)

Slika 3. List kružne pile 2 s promjenjivim korakom zubi i tijelom s dilatacijskim pukotinama (Svoreň i sur., 2013.) 


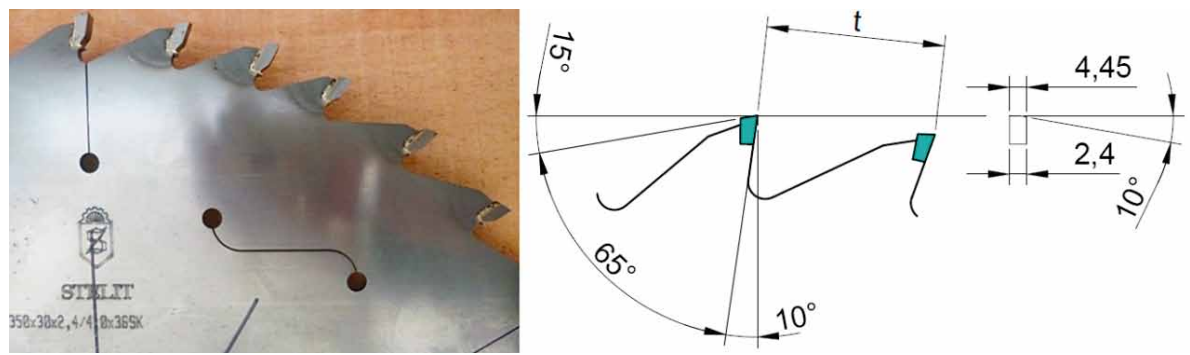

Figure 4 Detail of tooth of circular saw blade 2

Slika 4. Detalj zubi lista kružne pile 2

Table 2 Parameters of circular saw blades

Tablica 2. Parametri listova kružnih pila

\begin{tabular}{|c|c|c|c|c|c|}
\hline $\begin{array}{l}\text { Circular saw } \\
\text { blade } \\
\text { List kružne pile }\end{array}$ & $\begin{array}{c}\text { Geometry } \\
\text { Kutovi oštrice } \\
\left({ }^{\circ}\right)\end{array}$ & $\begin{array}{c}\text { Basic dimensions } \\
\text { Osnovne dimenzije } \\
D \times b \\
s \times d \\
\mathrm{~mm}\end{array}$ & $\begin{array}{c}\text { Tooth spacing } \\
\text { Korak zubi } \\
t, \mathrm{~mm}\end{array}$ & $\begin{array}{c}\text { Extension of the cutting } \\
\text { edge to the side } \\
\text { Jednostrano proširenje } \\
\text { oštrice } \\
a, \mathrm{~mm}\end{array}$ & $\begin{array}{c}\text { No. of teeth } \\
\text { Broj zubi }\end{array}$ \\
\hline No. 1 & & & & & \\
\hline$\alpha$ & 15 & \multirow{3}{*}{$\begin{array}{l}350 \times 4 \\
2.4 \times 30\end{array}$} & \multirow{3}{*}{$\begin{array}{l}\text { regular } \\
\text { jednak }\end{array}$} & \multirow{3}{*}{0.8} & \multirow{3}{*}{36} \\
\hline$\beta$ & 65 & & & & \\
\hline$\gamma$ & 10 & & & & \\
\hline \multicolumn{6}{|l|}{ No. 2} \\
\hline$\alpha$ & 15 & \multirow{3}{*}{$\begin{array}{l}350 \times 4 \\
2.4 \times 30\end{array}$} & \multirow{3}{*}{$\begin{array}{l}\text { irregular } \\
\text { promjenjiv }\end{array}$} & \multirow{3}{*}{0.8} & \multirow{3}{*}{36} \\
\hline$\beta$ & 65 & & & & \\
\hline$\gamma$ & 10 & & & & \\
\hline
\end{tabular}

output clutch of a torque sensor, and shaft, to the circular saw blade.

The processed material is caught in the feed part by the lever mechanism, which provides an adequate holding. The feed of the processed object is provided

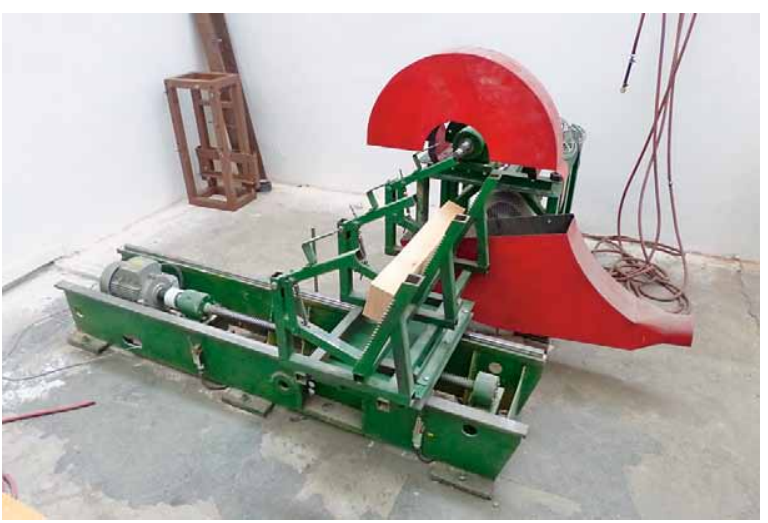

Figure 5 Measuring equipment for cross-cutting wood Slika 5. Stroj za eksperimentalno poprečno rezanje drva by an electric motor of $5.5 \mathrm{~kW}$, a safety clutch GIFLEX GFLL -28 and feed spring.

The signal from the torque sensor is transferred by the cables to the recording device called SPIDER 8 , which is connected to the PC. Using a torque sensor HBM T20WN, it is possible to record circular saw blade revolutions. Performance and revolutions of electric motors can be regulated by frequency changer with vector controlling (Mikleš et al., 2010).

\subsection{Measuring equipment}

2.3. Mjerna oprema

The measurement was performed by the following equipment (Fig. 6):

- Measuring equipment - SPIDER - 8

- Torque and revolution sensor - HBM T20WN

- Computer with analytic software

Measurement of revolutions and torque of a circular saw blade was performed by the sensor HBM T20WN (Fig. 6). The sensor is self-powered with volt-

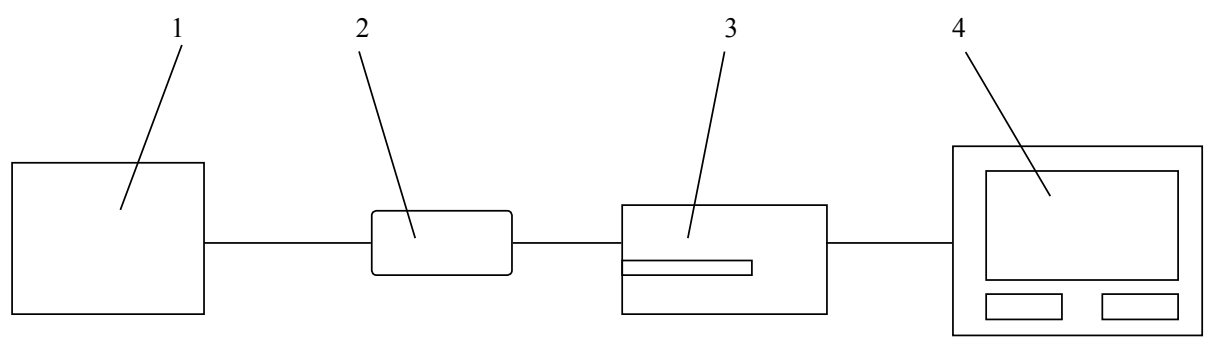

Figure 6 Measuring scheme: 1 - Measuring equipment, 2 - Torque and revolution sensor HBM T20WN, 3 - Measuring equipment SPIDER-8, 4 - PC with analytical software and a recording device

Slika 6. Mjerna shema: 1 - mjerna oprema, 2 - senzor zakretnog momenta i okretaja HBM T20WN, 3 - mjerna oprema SPIDER-8, 4 - PC s analitičkim softverom i uređajem za snimanje 
age of $12 \mathrm{~V}$. It has two output signals. It is a tensometric sensor of torque, revolutions and rotation angle. The sensor measures the nominal torque of up to 20 $\mathrm{N} \cdot \mathrm{m}$, but it is possible to load it up to $108 \mathrm{~N} \cdot \mathrm{m}$. It is protected by flexible clutches, which provide protection of a sensor against the deviations and vibrations caused by shaft defects. They also prevent it to transfer torque over $60 \mathrm{~N} \cdot \mathrm{m}$. (www.hbm.com).

The data from a sensor are sent to the measuring equipment SPIDER - 8 (Fig. 6). It is a universal measuring control panel (A/D transmitter), with eight channels, from which data are recorded to the computer hard disc. (www.hbm.com)

\section{RESULTS}

\section{REZULTATI}

The goal of the measurement was to search and evaluate energy consumption in the wood cross-cutting process. The measured data of cutting power were analyzed by analytic software STATISICA 12.

The observed factors and results are shown in Tab. 3. The observed factors were: wood species (spruce, pine, beech) with sample dimensions $50 \mathrm{~mm} \times 200 \mathrm{~mm}$ $\mathrm{x} 1000 \mathrm{~mm}$, two types of circular saw blades and three feed velocities $\left(v_{\mathrm{f}}=4,8,12 \mathrm{~m} \cdot \mathrm{min}^{-1}\right)$. The test was carried out at nominal revolutions $n=3000 \mathrm{~min}^{-1}$.

First, one-way analysis was performed, where one-dimensional effects were observed. The effect of factors was confirmed in all effects except for wood species where $p=0.247$. This means that wood species is not a significant factor. From the statistical point of view, it can be said that the effect of tooth pitch on the power output $P_{\mathrm{c}}$ has a $75 \%$ probability.

Table 4 shows the results of ANOVA for all feed velocities, circular saw blades and wood species. All these factors were statistically very significant. The level of significance $p$ must be lower than 0.05 to ob-

Table 3 Mean values of cutting power $P_{\mathrm{c}}$ for circular saw blade 1 and 2

Tablica 3. Prosječne vrijednosti snage rezanja $P_{\mathrm{c}}$ kružnih pila 1 i 2

\begin{tabular}{|c|c|c|c|c|c|c|c|c|}
\hline \multicolumn{3}{|c|}{$\begin{array}{c}\text { Cutting power } \boldsymbol{P}_{\boldsymbol{c}}, \mathbf{k W} \\
\text { Snaga rezanja } P_{c}, \mathrm{~kW}\end{array}$} & \multicolumn{3}{|c|}{$\begin{array}{c}\text { Cutting power } \boldsymbol{P}_{c}, \mathbf{k W} \\
\text { Snaga rezanja } P_{c}, \mathrm{~kW}\end{array}$} & \multicolumn{3}{|c|}{$\begin{array}{c}\text { Cutting power } \boldsymbol{P}_{\boldsymbol{c}}, \mathbf{k W} \\
\text { Snaga rezanja } P_{c}, \mathrm{~kW}\end{array}$} \\
\hline \multirow{4}{*}{$\begin{array}{c}\text { Wood } \\
\text { species } \\
\text { Vrsta drva }\end{array}$} & \multicolumn{2}{|c|}{$\begin{array}{l}\text { Circular saw blade } \\
\text { List kružne pile }\end{array}$} & \multirow{4}{*}{$\begin{array}{l}\text { Wood } \\
\text { species } \\
\text { Vrsta drva }\end{array}$} & \multicolumn{2}{|c|}{$\begin{array}{l}\text { Circular saw blade } \\
\text { List kružne pile }\end{array}$} & \multirow{4}{*}{$\begin{array}{c}\text { Wood } \\
\text { species } \\
\text { Vrsta drva }\end{array}$} & \multicolumn{2}{|c|}{$\begin{array}{l}\text { Circular saw blade } \\
\text { List kružne pile }\end{array}$} \\
\hline & 1 & 2 & & 1 & 2 & & 1 & 2 \\
\hline & \multicolumn{2}{|c|}{$\begin{array}{c}\text { Feed velocity } \\
\text { Posmična brzina } \\
v_{f}, \mathrm{~m} \cdot \mathrm{min}^{-1} \\
\end{array}$} & & \multicolumn{2}{|c|}{$\begin{array}{l}\text { Feed velocity } \\
\text { Posmična brzina } \\
v_{f}, \mathrm{~m} \cdot \mathrm{min}^{-1}\end{array}$} & & \multicolumn{2}{|c|}{$\begin{array}{c}\text { Feed velocity } \\
\text { Posmična brzina } \\
v_{f}, \mathrm{~m} \cdot \mathrm{min}^{-1} \\
\end{array}$} \\
\hline & 4 & 4 & & 8 & 8 & & 12 & 12 \\
\hline $\begin{array}{l}\text { spruce } \\
\text { smreka }\end{array}$ & 1.47 & 1.54 & $\begin{array}{l}\text { spruce } \\
\text { smreka }\end{array}$ & 2.26 & 2.35 & $\begin{array}{l}\text { spruce } \\
\text { smreka }\end{array}$ & 2.94 & 3.32 \\
\hline $\begin{array}{l}\text { spruce } \\
\text { smreka }\end{array}$ & 1.55 & 1.97 & $\begin{array}{l}\text { spruce } \\
\text { smreka }\end{array}$ & 1.96 & 2.39 & $\begin{array}{c}\text { spruce } \\
\text { smreka }\end{array}$ & 2.77 & 3.23 \\
\hline $\begin{array}{l}\text { spruce } \\
\text { smreka }\end{array}$ & 1.54 & 1.70 & $\begin{array}{l}\text { spruce } \\
\text { smreka }\end{array}$ & 1.94 & 2.37 & $\begin{array}{l}\text { spruce } \\
\text { smreka }\end{array}$ & 2.78 & 3.10 \\
\hline $\begin{array}{l}\text { spruce } \\
\text { smreka }\end{array}$ & 1.51 & 1.68 & $\begin{array}{l}\text { spruce } \\
\text { smreka }\end{array}$ & 1.92 & 2.42 & $\begin{array}{c}\text { spruce } \\
\text { smreka }\end{array}$ & 2.85 & 3.10 \\
\hline $\begin{array}{l}\text { spruce } \\
\text { smreka }\end{array}$ & 1.54 & 1.63 & $\begin{array}{l}\text { spruce } \\
\text { smreka }\end{array}$ & 2.26 & 2.40 & $\begin{array}{l}\text { spruce } \\
\text { smreka }\end{array}$ & 2.66 & 3.07 \\
\hline $\begin{array}{l}\text { pine } \\
\text { bor }\end{array}$ & 1.40 & 1.66 & $\begin{array}{l}\text { pine } \\
\text { bor }\end{array}$ & 2.18 & 2.64 & $\begin{array}{l}\text { pine } \\
\text { bor }\end{array}$ & 2.84 & 3.27 \\
\hline $\begin{array}{l}\text { pine } \\
\text { bor }\end{array}$ & 1.69 & 1.58 & $\begin{array}{l}\text { pine } \\
\text { bor }\end{array}$ & 2.35 & 2.57 & $\begin{array}{l}\text { pine } \\
\text { bor }\end{array}$ & 2.87 & 3.38 \\
\hline $\begin{array}{l}\text { pine } \\
\text { bor }\end{array}$ & 1.70 & 1.62 & $\begin{array}{l}\text { pine } \\
\text { bor }\end{array}$ & 2.39 & 2.56 & $\begin{array}{l}\text { pine } \\
\text { bor }\end{array}$ & 2.83 & 3.12 \\
\hline $\begin{array}{l}\text { pine } \\
\text { bor }\end{array}$ & 1.64 & 1.59 & $\begin{array}{l}\text { pine } \\
\text { bor }\end{array}$ & 2.40 & 2.85 & $\begin{array}{l}\text { pine } \\
\text { bor }\end{array}$ & 2.86 & 3.11 \\
\hline $\begin{array}{l}\text { pine } \\
\text { bor }\end{array}$ & 1.57 & 1.60 & $\begin{array}{l}\text { pine } \\
\text { bor }\end{array}$ & 2.03 & 2.64 & $\begin{array}{l}\text { pine } \\
\text { bor }\end{array}$ & 2.53 & 3.27 \\
\hline $\begin{array}{l}\text { beech } \\
\text { bukva }\end{array}$ & 1.68 & 1.68 & $\begin{array}{l}\text { beech } \\
\text { bukva }\end{array}$ & 2.45 & 2.95 & $\begin{array}{l}\text { beech } \\
\text { bukva }\end{array}$ & 2.99 & 3.31 \\
\hline $\begin{array}{l}\text { beech } \\
\text { bukva }\end{array}$ & 1.63 & 1.89 & $\begin{array}{l}\text { beech } \\
\text { bukva }\end{array}$ & 2.68 & 2.59 & $\begin{array}{l}\text { beech } \\
\text { bukva }\end{array}$ & 3.27 & 3.16 \\
\hline $\begin{array}{l}\text { beech } \\
\text { bukva }\end{array}$ & 1.64 & 1.99 & $\begin{array}{l}\text { beech } \\
\text { bukva }\end{array}$ & 2.64 & 2.61 & $\begin{array}{l}\text { beech } \\
\text { bukva }\end{array}$ & 3.28 & 3.18 \\
\hline $\begin{array}{l}\text { beech } \\
\text { bukva }\end{array}$ & 1.65 & 1.93 & $\begin{array}{l}\text { beech } \\
\text { bukva }\end{array}$ & 2.59 & 2.66 & $\begin{array}{l}\text { beech } \\
\text { bukva }\end{array}$ & 3.26 & 3.23 \\
\hline $\begin{array}{l}\text { beech } \\
\text { bukva }\end{array}$ & 1.66 & 1.80 & $\begin{array}{l}\text { beech } \\
\text { bukva }\end{array}$ & 2.54 & 2.59 & $\begin{array}{l}\text { beech } \\
\text { bukva }\end{array}$ & 3.33 & 3.27 \\
\hline
\end{tabular}




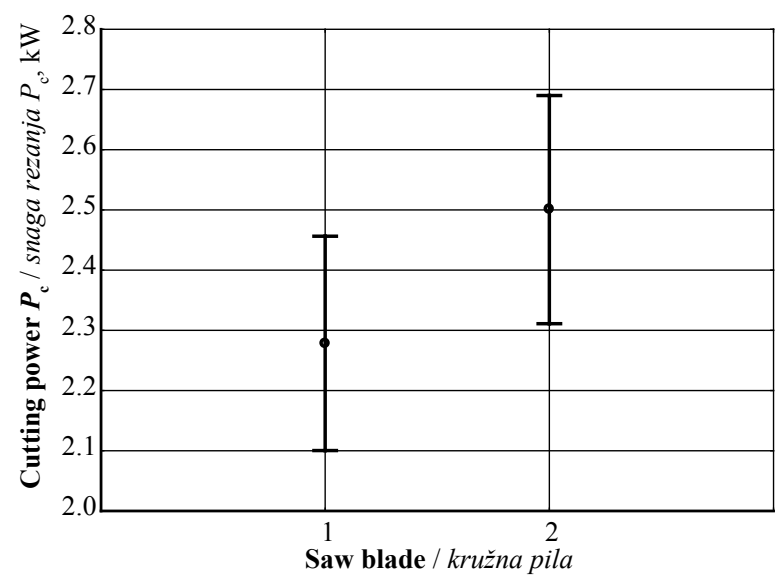

Figure 7 Impact of circular saw blade type on cutting power in sawing researched wood species

Slika 7. Utjecaj vrste kružne pile na snagu rezanja tijekom piljenja ispitivanih vrsta drva

tain the results that are statistically significant and valid. The highest interaction with the cutting process was caused by feed velocity $v_{\mathrm{f}}$, followed by the type of circular saw blade and wood species.

Circular saw blade 1 has regular tooth pitch and a full body. Circular saw blade 2 has the same geometry of tooth made of sintered carbide inserts but it has a different shape of tooth, irregular tooth pitch and dilatation gaps.

Figure 7 it is clear that circular saw blade 2 with the same geometry of angles $\alpha, \beta, \gamma$ as circular saw blade 1 but different tooth spacing and dilatation gaps has higher energy consumption than circular saw blade 1 . From the statistical point of view, the interaction of circular saw blade 2 is higher that the interaction of circular saw blade 1. It is supported by the level of significance $p<0.0001$ thereby there was confirmed influence of tooth spacing on energy consumption of cross-cutting wood.

Figure 8 shows the dependence between feed velocity $\left(v_{\mathrm{f}}=4,8,12 \mathrm{~m} \cdot \mathrm{min}^{-1}\right)$ and cutting power. The cutting power increases with increasing feed velocity. The curve is significantly linear. The course of cutting power is increasing in the whole range of chosen feed velocities.

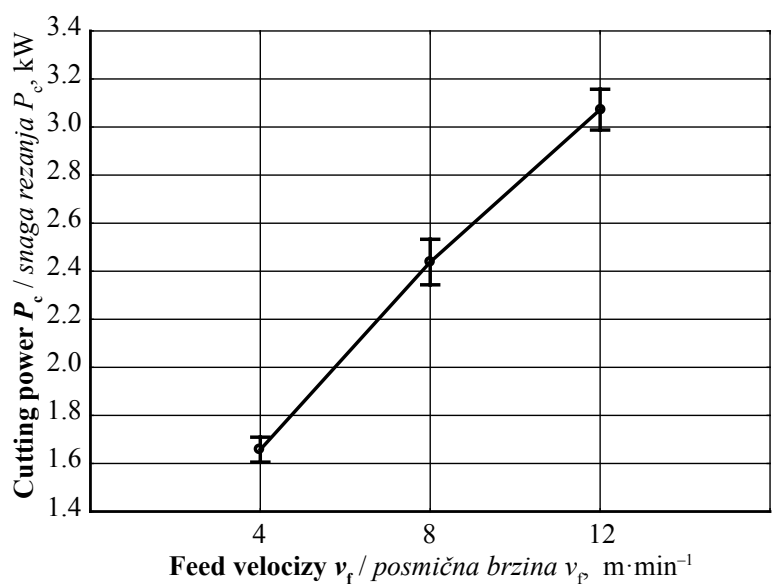

Figure 8 Impact of feed velocity on cutting power during sawing researched wood species

Slika 8. Utjecaj posmične brzine na snagu rezanja tijekom piljenja ispitivanih vrsta drva

The influence of wood species in the process of cross-cutting wood, i.e. cutting power, is shown in Figure 9. Three wood species were compared - spruce,

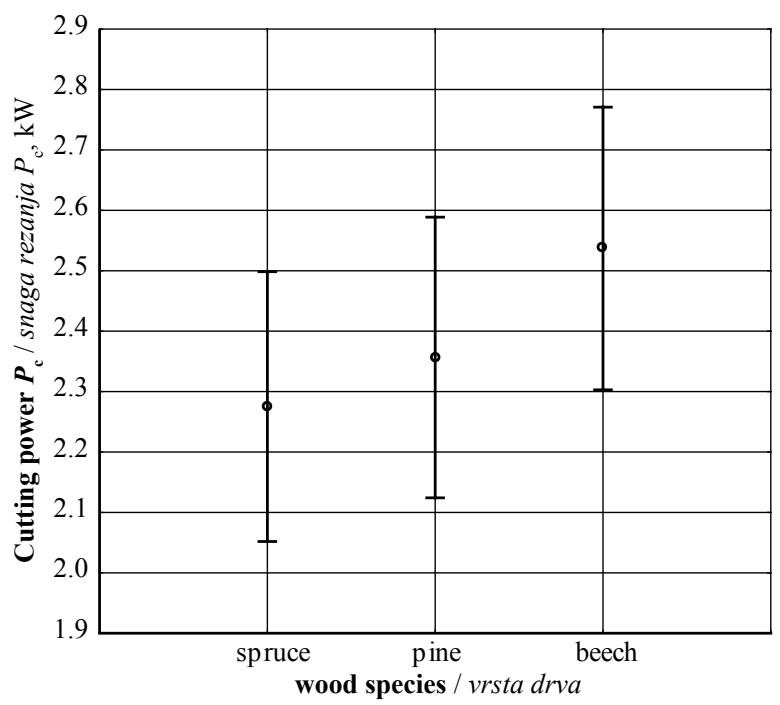

Figure 9 Impact of wood species (spruce, pine, beech) on cutting power for all feed velocities

Slika 9. Utjecaj vrste drva (smrekovina, borovina, bukovina) na snagu rezanja pri različitim posmičnim brzinama

Table 4 Basic analysis of variance of measurement results

Tablica 4. Osnovna analiza varijance mjerenjem dobivenih podataka

\begin{tabular}{|c|c|c|c|c|c|}
\hline Effect / Utjecajni činitelj & $\begin{array}{c}\text { Sum of } \\
\text { squares } \\
\text { Zbroj } \\
\text { kvadrata }\end{array}$ & \begin{tabular}{|c} 
Degrees of \\
freedom \\
Stupanj \\
slobode
\end{tabular} & $\begin{array}{l}\text { Variance } \\
\text { Varijanca }\end{array}$ & $\begin{array}{c}\text { Fisher's } \\
\text { F-test }\end{array}$ & $\begin{array}{c}\text { Level of } \\
\text { significance } \\
\text { Razina } \\
\text { signifikantnosti } \\
p \\
\end{array}$ \\
\hline Circular saw blade / list kružne pile & 1.11 & 1 & 1.11 & 84 & $<0.0001$ \\
\hline Feed velocity / posmična brzina, $\mathrm{m} \cdot \mathrm{min}^{-1}$ & 30.13 & 2 & 15.06 & 1135 & $<0.0001$ \\
\hline Wood species / vrsta drva & 1.08 & 2 & 0.54 & 41 & $<0.0001$ \\
\hline $\begin{array}{l}\text { Circular saw blade * Feed velocity }\left(\mathrm{m} \cdot \mathrm{min}^{-1}\right) \\
\text { list kružne pile * posmična brzina }\left(\mathrm{m} \cdot \mathrm{min}^{-1}\right)\end{array}$ & 0.09 & 2 & 0.05 & 4 & 0.033 \\
\hline $\begin{array}{l}\text { Circular saw blade * Wood species } \\
\text { list kružne pile * vrsta drva }\end{array}$ & 0.17 & 2 & 0.08 & 6 & 0.003 \\
\hline $\begin{array}{l}\text { Feed velocity } v_{f}\left(\mathrm{~m}^{\text {Finin }} \mathrm{mi}^{-1}\right) \text { Wood species } \\
\text { posmična brzina }\left(\mathrm{m} \cdot \mathrm{min}^{-1}\right) * \text { vrsta drva }\end{array}$ & 0.24 & 4 & 0.06 & 4 & 0.003 \\
\hline $\begin{array}{l}\text { Circular saw blade*Feed velocity }\left(\mathrm{m} \cdot \mathrm{min}^{1}\right)^{*} \text { Wood species } \\
\text { list kružne pile * posmična brzina }\left(\mathrm{m} \cdot \mathrm{min}^{-1}\right)^{*} \text { vrsta drva }\end{array}$ & 0.28 & 4 & 0.07 & 5 & 0.001 \\
\hline
\end{tabular}


... Krilek, Ťavodová, Kováč, Tichý: Impact of Irregular Tooth Pitch of Circular Saw Blades...
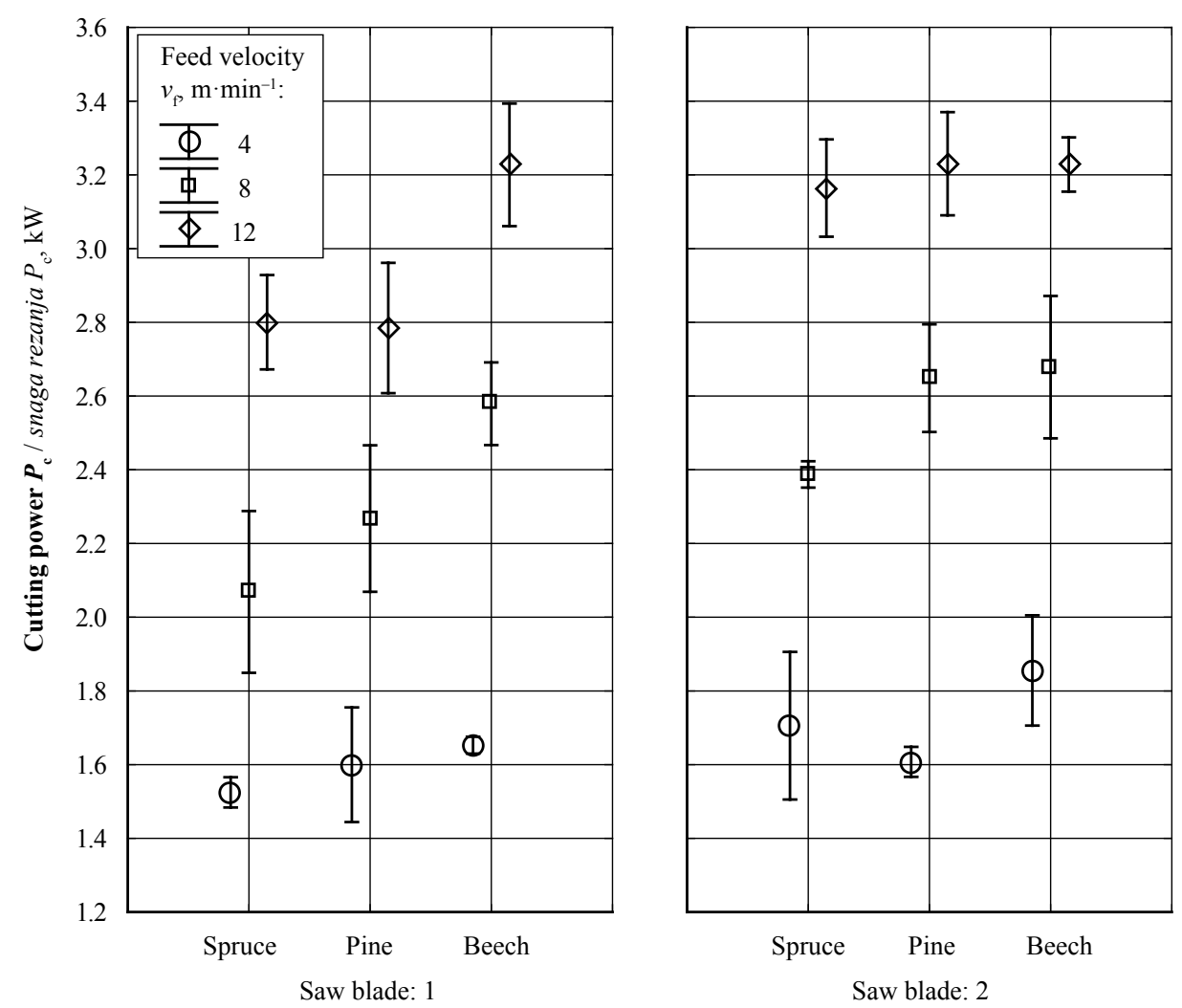

Figure 10 Impact of wood species (spruce, pine, beech), feed velocities $\left(v_{\mathrm{f}}=4,8,12 \mathrm{~m} \cdot \mathrm{min}^{-1}\right)$ and type of circular saw blade (type 1 and 2) on wood cross-cutting process

Slika 10. Utjecaj vrste drva (smrekovine, borovine, bukovine), posmične brzine $\left(v_{\mathrm{f}}=4,8,12 \mathrm{~m} \cdot \mathrm{min}^{-1}\right)$ i vrste kružne pile (tip 1 i 2) na postupak poprečnog rezanja drva

pine and beech. Beech consumed most energy. The lowest cutting power $P_{\mathrm{c}}$ was shown in the case of spruce.

Figure 10 shows a graph of $95 \%$ confidence of factors affecting wood cross-cutting process i.e. spruce, pine, beech, feed velocity $\left(v_{\mathrm{f}}=4,8,12 \mathrm{~m} \cdot \mathrm{min}^{-1}\right)$ and type of circular saw blade 1 and 2 .

The graph (Fig. 10) clearly shows that circular saw blade 1 with regular tooth pitch and a full body is better for wood cross-cutting process for the chosen factors. Similar values of cutting power to those of circular saw blade 2 with irregular tooth pitch and dilatation gaps were obtained in cutting pine and at the feed velocity $v_{\mathrm{f}}=4 \mathrm{~m} \cdot \mathrm{min}^{-1}$. There were also less significant differences in cutting beech and at the feed velocity $v_{f}$ $=8,12 \mathrm{~m} \cdot \mathrm{min}^{-1}$. The levels of cutting power in cutting beech were the highest for all cutting speeds. From the graph in Figure 10, it is clear that the cutting power increases with increasing feed velocity.

Nearly the same results were obtained for spruce and beech and at the feed velocity $v_{\mathrm{f}}=4 \mathrm{~m} \cdot \mathrm{min}^{-1}$. This fact can also be observed at the feed velocity $v_{\mathrm{f}}=12$ $\mathrm{m} \cdot \mathrm{min}^{-1}$. More significant difference was observed at the feed velocity $v_{\mathrm{f}}=8 \mathrm{~m} \cdot \mathrm{min}^{-1}$.

Circular saw blade 1 had the lowest difference in cutting power for all wood species at the feed velocity $v_{\mathrm{f}}=4 \mathrm{~m} \cdot \mathrm{min}^{-1}$. Circular saw blade 2 had this feature at a higher feed velocity $v_{\mathrm{f}}=12 \mathrm{~m} \cdot \mathrm{min}^{-1}$.

There was almost no difference between circular saw blades during beech cutting. The difference be- tween circular saw blades for spruce and pine cutting was nearly the same.

The measurement showed that circular saw blade 1 had better first contact with processed material. Circular saw blade 2 had higher vibrations, bigger cutting area and cutting power.

Circular saw blade 1 is more suitable for the wood cross-cutting process than circular saw blade 2 . Circular saw blade 2 should be used for longitudinal wood cutting, where longer time of cutting is necessary, providing enough time for the stabilization of a circular saw blade, which is important for reducing the effects of its parameters e.g. tension of dilatation gaps and vibrations.

\section{DISCUSSION \\ 4. RASPRAVA}

In this study, the effect was assessed of feed velocity, saw blade and wood species on the cutting power $P_{\mathrm{c}}$ of spruce (Picea abies), pine (Pinus sylvestris) and beech (Fagus silvatica) wood during sawing with a guided circular saw. The aim of the measurement was to search and evaluate energy consumption in the wood cross-cutting process. The measured data of cutting power were analyzed by analytic software STATISICA 12. The cutting power increases with increasing feed velocity. The curve is significantly linear. Average chip thickness is a critical factor in the sawing process as it greatly affects the cutting power (Nasir et al., 2018). 
This is in accordance with what is reported in the literature (Axelsson et al., 1993; Vazquez- Cooz et al., 2006; Aguilera, 2011; Cristóvão et al., 2012). The result confirms previous cross-cutting wood tests of energy consumption (Koljozov et al., 2015; Kopecký et al., 2014; Krilek et al., 2014; Orlowski et al., 2006; Kminiak, 2007; Orlicz, 1988). The course of cutting power is increasing in the whole range of chosen feed velocities. The highest energy consumption was measured for beech. To sum up, the specific cutting resistance decreases with the increasing chip thickness (Kopecký et al., 2014). The formula for the calculation of the cutting power $P_{\mathrm{c}}=K_{\mathrm{c}} \cdot b \cdot e \cdot v_{\mathrm{f}}$ and Figure 2 confirm this assertion. This phenomenon is known from metal machining, and it was also noticed in wood cutting with circular saw blades (Manžos, 1974; Orlowski, 2010; Orlowski et al., 2013; Kopeck et al., 2014) and in wood milling (Durkovic et al., 2018). The lowest cutting power $P_{\mathrm{c}}$ was observed in the case of spruce. The result confirms previous cross-cutting wood tests of energy consumption (Krilek et al., 2014; Kminiak, 2007; Kopecký et al., 2014).

\section{CONCLUSIONS}

\section{ZAKLJUČAK}

1. The highest cutting power is required for deciduous wood - beech, at all feed velocities $\left(v_{\mathrm{f}}=4,8\right.$, $12 \mathrm{~m} \cdot \mathrm{min}^{-1}$ ) and circular saw blades used in the research.

2. With increasing feed velocity, energy consumption of the cutting process also increases. Feed velocity has the highest influence on the wood crosscutting process and cutting power $P$.

3. Circular saw blade 1 with regular tooth pitch had lower energy consumption in the wood cross-cutting process than circular saw blade 2 with irregular tooth pitch for all tested wood species (spruce, pine, beech) and feed velocities $\left(v_{\mathrm{f}}=4,8,12 \mathrm{~m} \cdot \mathrm{min}^{-1}\right)$.

\section{Acknowledgments - Zahvala}

The authors are grateful for the support of the Scientific Grant Agency of the Ministry of Education, Science, Research, and Sport of the Slovak Republic, Project VEGA No. 1/0609/2020 „Research of the cutting tools at the dendromass processing in agricultural and forestry production".

\section{REFERENCES}

\section{LITERATURA}

1. Aguilera, A., 2011: Cutting energy and surface roughness in medium density fiberboard rip sawing. Eur. J. Wood Prod., 69: 11-18. https://doi.org/10.1007/s00107-009-0396-z.

2. Argay, F., 2014: Effect of the saw blade teeth number on transverse cutting process noise when cutting beechwood. Acta facultatis xylologiae Zvolen, 56 (1): 77-85.

3. Atkins, A. G., 2009: The science and engineering of cutting. The mechanics and process of separating, scratching and puncturing biomaterials, metals and non-metals. Butterworth-Heinemann is an imprint of Elsevier, Oxford.
4. Axelsson, B. O.; Lundberg, Å. S.; Grönlund, J. A, 1993: Studies of the main cutting force at and near a cutting edge. Eur J Wood Prod, 51 (2): 43-48.

5. Banski, A., 2000: Údržba pílového kotúča so spekanými karbidmi (in Slovak) [Maintenance of saw blade with sintered carbides]. In Drevorezné nástroje, Starostlivost' a bezpečnost' pri práci. TU Zvolen, Zvolen, Slovakia, p. 76-85.

6. Barcík, Š.; Pivolusková, E.; Kminiak, R., 2008: Effect of technological parameters and wood properties on cutting power in plane milling of juvenile poplar wood. Drvna industrija, 59 (3): 34-41.

7. Barcík, Š.; Pivolusková, E.; Kminiak, R.; Wieloch, G., 2009: The Influence of Cutting Speed and Feed Speed on Surface Quality at Plane Milling of Poplar Wood. Wood Research, 54 (2): 109-115.

8. Bradbury, S. R.; Lewis, D. B., 2000: A Comparasion of the performance and wear characteristics of high-speed steel circular saw blades machining Tool Steel. Journal of material science, 35: 1511-1524. https://doi.org/10.1023/A:1004749400522.

9. Cristóvão, L.; Broman, O.; Grönlund, A.; Ekevad, M.; Sitoe, R., 2012: Main cutting force models for two species of tropical wood. Wood Mat Sci Eng, 7 (3): 143-149. https://doi.org/10.1080/17480272.2012.662996.

10. Danwé, R.; Bindzi, I.; Meva'a, L., 2012: Optimization of cutting in primary wood transformation industries. Journal of Industrial Engineering and Management. JIEM, 5 (1): 115-132.

11. Durkovic, M.; Mladenovic, G.; Tanovic, L.; Danon, G., 2018: Impact of feed rate, milling depth and tool rake angle in peripheral milling of oak wood on the cutting force. In Maderas: Ciencia y Tecnologia., 20 (1): 25-34. http://dx.doi.org/10.4067/S0718-221X2018005001301.

12. Goglia, V., 1994: Strojevi i alati za obradu drva I. Zagreb, GRAFA, $235 \mathrm{p}$.

13. Kminiak, R.; Kubš, J., 2016: Cutting Power during Cross-Cutting of Selected Wood Species with a Circular Saw. BioResources, 11 (4), 10528-10539. http://dx.doi.org/10.15376/biores.11.4.10528-10539.

14. Kminiak, R.; Gašparík, M.; Kvietková, M., 2015: The Dependence of Surface Quality on tool Wear of Circular Saw Blades during transversal Sawing of Beech Wood. BioResources, 10 (4): 7123-7135. http://dx.doi.org/10.15376/biores.10.4.7123-7135.

15. Kminiak, R., 2007: Znižovanie opotrebovania ostria metódou “tip-inserted teeth" pre kmeňové pásové a kmeňové kotúčové píly (In Slovak) [Reducing wear of the blade using the "tip-inserted teeth" to stem tribal belt and circular saws]. In Drevorezné nástroje a obrábanie dreva 2007: zborník referátov z odborného seminára. TU Zvolen, Zvolen, p. 96-101.

16. Koljozov, V.; Trposki, Z.; Rabadjiski, B.; Zlateski, G., 2015: Research on the effects of the number of circular saw blades on the cutting force and the cutting power. International Journal - Wood, Design \& Technology, 4 (1): 30-34.

17. Kopecký, Z.; Hlásková, L.; Orlowski, K., 2014: An innovative approach to prediction energetic effects of wood cutting process with circular-saw blades. Wood Research, 59 (5): 827-834.

18. Kováč, J.; Mikleš, M., 2009: Vplyv vybraných parametrov na energetickú náročnost' procesu rezania dreva pílovými kotúčmi (in Slovak) [The influence of selected parameters on energy consumption of the cutting process wood saw blades]. In Výrobné inžinierstvo, č. 3, Slovakia, p. 23-26. 
19. Krilek, J.; Kovač. J.; Kučera, M., 2014: Wood crosscutting process analysis for circular saws. BioResources, 9 (1): $1417-1429$. http://dx.doi.org/10.15376/biores.9.1.1417-1429.

20. Kvietková, M.; Gaff, M.; Gašparík, M.; Kminiak, R.; Kriš, A., 2015: Effect of number of saw blade teeth on noise level and wear of blade during cutting of wood. BioResources, 10 (1): 1657-1666. http://dx.doi.org/10.15376/biores.10.1.1657-1666.

21. Lisičan, J., 1982: Základy obrábania a delenia drevných materiálov (in Slovak) [Basic of Machining and cutting wood materials]. Zvolen, VŠLD, p. 386.

22. Manžos, F. M., 1974: Derevorežuŝie Stanki (in Rusian) [Wood cutting machine tools] Publisher Lesnaâ promyšlennost [Forest industry]. Moskva.

23. Mikleš, M.; Kováč, J.; Krilek, J., 2010: Výskum rezných podmienok priečneho pílenia dreva (in Slovak) [Research of cutting process of cross-cutting wood]. Research study. Zvolen, Technická univerzita vo Zvolene, p. 69.

24. Nasir, V.; Cool, J., 2019: Optimal power consumption and surface quality in the circular sawing process of Douglas-fir wood, Eur. J. Wood Prod., 77 (4): 609-617. https://doi.org/10.1007/s00107-019-01412-z.

25. Naylor, A.; Hackney, P.; Perera, N.; Clahr, E., 2012: A predictive model for the cutting force in wood machining developed using mechanical properties. BioResources, 7 (3): 2883-2894.

26. Orlicz, T., 1988: Obróbka drewna narzędziami tnącymi (in Polish) [Wood machining with cutting tools]. Skrypty SGGW-AR w Warszawie, Wydawnictwo SGGW-AR, Warszawa.

27. Orlowski, K. A., 2007: Experimental studies on specific cutting resistance while cutting with narrow-kerf saws. Advances in Manufacturing Science and Technology, 31 (1): 49-63.

28. Orlowski, K. A., 2010: The fundamentals of narrow-kerf sawing: Mechanics and quality of cutting. Technical University in Zvolen, pp. 1-123. ISBN 978-80-228-2140-7.

29. Orlowski, K. A.; Sandak, J.; Negri, M.; Dzurenda, L., 2009: Sawing frozen wood with narrow kerf saws: Energy and quality effects. Forest Products Journal, 59 (3): 79-83.

30. Orlowski, K. A.; Ochrymiuk, T.; Atkins, T.; Chuchala, D., 2013: Application of fracture mechanics for energetic effects predictions while wood sawing. Wood Science and Technology, 47 (5): 949-963. DOI: 10.1007/s00226-013-0551-x.

31. Požgaj, A.; Chovanec, D.; Kurjatko, S.; Babiak, M., 1997: Štruktúra a vlastnosti dreva (in Slovak) [Structure and properties of wood]. Príroda, a. s. Bratislava, Slovakia, p. 485.

32. Schajer, G. S.; Wang, S. A., 2002: Effect of workpiece interaction on circular saw cutting stability II. Holz als Roh und Werkstoff, 60: 48-54.

33. Scholz, F.; Duss, R.; Hasslinger, R.; Ratnasingam, J., 2009: Integrated model for the prediction of cutting forces, pp. 183-190. In: Handong Zhou, Nanfeng Zhu, Tao Ding (eds.). Proc. of $19^{\text {th }}$ International Wood Machining Seminar, October 21-23, Nanjing, China, Nanjing Forestry University.

34. Siklienka, M.; Argay, F.; Kminiak, R., 2012: Vplyv uhlovej geometrie pílového kotúča na kvalitu povrchu pri priečnom pílení rastlého dreva (in Slovak) [Effect of the saw blade angular geometry on surface quality by transverse sawing of solid wood]. In Chip and chipless woodworking processes 2012: the $8^{\text {th }}$ International Science Conference, September 6-8, 2012, Technical University in Zvolen. Zvolen, p. 325-332.

35. Siklienka, M.; Kminiak, R.; Argay, F., 2013: Vplyv uhlovej geometrie pílového kotúča na rezný výkon pri priečnom pílení bukového dreva (in Slovak) [Saw blade angle geometry effect on cutting output power by crosscutting of beech wood]. Acta Facultatis Xylologiae Zvolen, 55 (1): 91-99.

36. Siklienka, M.; Mišura, L', 2005: Vplyv presahu pílového kotúča a rýchlosti posuvu na rezný výkon. In Transfer 2005 - Využívanie nových poznatkov v strojárskej praxi. Trenčín, p. 464, Slovakia.

37. Strelkov, I. M., 2009: Povyšenie iznosostojkosti kruglyh pil dlâ poperečnoj raspilovki drevesiny metodom lazernoj termičeskoj obrabotki zub'ev [Increasing the wear resistance of circular saws for transverse sawing of wood by laser heat treatment of teeth]. $\mathrm{PhD}$ thesis [online]. [cit - 2015 - 20 - 09]. Available on the Internet: http://tekhnosfera.com/povyshenie-iznosostoykosti-kruglyh-pildlya-poperechnoy-raspilovki-drevesiny-metodom-lazernoy-termicheskoy-obrabotki-zubi.

38. Suhanov, V. G., 1984: Kruglopil'nye stanki dlâ raspilovki drevesiny [Circular sawing machines for wood] [online]. [cit - 2015 - 20 - 09]. Available on the Internet: http:// www.booksite.ru/fulltext/rusles/suhan/text.pdf.

39. Svoreň, J., 2002: Drevárske stroje. Čast' I. (in Slovak) [Woodworking machines. Part I.]. Zvolen: Technická univerzita vo Zvolene, $169 \mathrm{p}$.

40. Svoreň, J.; Javorek, L'; Hrubý, M., 2013: Pílový kotúč s kompenzačnými drážkami redukujúci hluk (zverejnená patentová prihláška): Patent n. 52-2013. Vestník ÚPV SR č. 02/2015. - Banská Bystrica: Úrad priemyselného vlastníctva Slovenskej republiky, 5 p., 4 fig. - Available on the Internet: http://registre.indprop.gov.sk/registre/pdf/patprihl/2013/20130052.pdf.

41. Vazquez-Cooz, I.; Meyer, R. W., 2006: Cutting forces for tension and normal wood of maple. For Prod J, 56 (4): 26 [online]. [cit - 2019-20-06]. Available on the Internet: http://www.fao.org/3/XII/0886-A2.htm.

42. Vladimirovič, Š. V., 2004: Rezanie drevesiny [Wood cutting] [online] [cit - 2015-20-09]. Available on the Internet: http://pnu.edu.ru/media/filer_public/2012/11/27/ rezanie.pdf.

43. Wasielewski, R.; Orlowski, K., 2002: Hybrid dynamically balanced saw frame drive. Holz als Roh- und Werkstoff, 60 (3): 202-206.

doi.org/10.1007/s00107-002-0290-4.

Corresponding address:

Assoc. Prof. JOZEF KRILEK, Ph.D.

Faculty of Technology

Technical University in Zvolen

Zvolen, SLOVAK REPUBLIC

e-mail: jkrilek@gmail.com 